\title{
INTEGRATED SOIL FERTILITY MANAGEMENT OF HYBRID COCONUT GROWN IN DIFFERENT AGRO-CLIMATIC CONDITIONS OF THE PHILIPPINES
}

\author{
by \\ R.Z Margate $^{1}$, M.I Secretaria ${ }^{1}$, G.D. Padrones ${ }^{1}$, J.N. Maravilla ${ }^{1}$, S.S. Magat ${ }^{2}$, J.A. Mantiquilla ${ }^{1}$, \\ E. C Silva ${ }^{3}$, R. Corsame ${ }^{3}$, J Borromeo $^{3}$ and V. Rivera ${ }^{3}$
}

\begin{abstract}
Four fertilizer trials initiated in 1986 and completed eight years later were conducted to find out the effect of using organic fertilizers vis-a-vis lower and higher levels of inorganic fertilizers and organic plus inorganic fertilizer combinations on hybrid coconuts.

In all sites the application of inorganic fertilizers (both lower and higher levels of ammonium sulfate $+\mathrm{KCl}$ or $\mathrm{NaCl}$ ) produced significant increases m nut yield, copra weight per nut and copra per tree but lowered soil $\mathrm{pH}$. These increases in Yield, copra were closely associated with the correction of $\mathrm{N}$ and $\mathrm{Cl}$ deficiencies of the palms. The most profitable treatment was the lower inorganic fertilizer level followed by treatment where ammonium sulfate was substituted with organic fertilizers (organic $+\mathrm{KCl}$ or $\mathrm{NaCl}$ ). A commercial organic Sagana 100 fertilizer either applied singly or in combination with inorganic $\mathrm{Cl}$ proved argonomically effective but its prohibitive cost made it uneconomical to use. Apparently organic fertilizers which are available in the farms and are much cheaper proved economical but need to be combined with $\mathrm{Cl}$ to be effective.
\end{abstract}

\section{INTRODUCTION}

In the late seventies, field fertilizer trials were conducted only in the Mindanao provinces using chemical or inorganic fertilizers. These trials produced impressive results. But more data are still needed especially for hybrid in practically all parts of the country and local tall in the Visayas and Luzon.

These field trials and those conducted in the research centers revealed positive responses to inorganic fertilization especially when $\mathrm{N}, \mathrm{Cl}$ and $\mathrm{S}$ were present in the fertilizer materials (Prudente and Mendoza, 1976; Magat, et al., 1977; Margate et al., 1979). Improvement mi nut and copra production per nut or per palm were common which were observed two years after the initial fertilizer application although slight increases were already noted even $\mathbf{M}^{\prime}$ the first year (Padrones et al., 1985). The noted increases in production with inorganic fertilization were always associated with increases in the $\mathrm{N}, \mathrm{Cl}$ and $\mathrm{S}$ levels in the leaves. The unfertilized palms, on the other hand, were generally found to have decreasing yield from year to year. Nowadays, however, the use of organic fertilizer in modem crop production has been gaining worldwide acceptance primarily due to environmental concern. Besides, a number of Asian countries like India, Thailand and the Philippines are also concerned with reducing the cost of the government's importation of chemical fertilizers. This is one of the thrusts of the government in conserving foreign exchange earnings. In 1992, the Philippines consumed 1.3 MT of chemical fertilizers of various grades (Mangawang, 1993). Of these, 1.13 MT were imported costing $\$ 168 \mathrm{M}$.

\footnotetext{
${ }^{1}$ Research Staff, Agronomy and Soils Division, PCA Davao Research Center, Bago Oshiro, Davao City.

${ }^{2}$ Manager, Agricultural Research Management Department PCA-Central Office, Diliman Quezon City.

${ }^{3}$ Agriculturists, PCA-Regional Offices at South Cotabato, Zamboanga City Albay and Cagayan Province.
} 
Hence research undertakings are gradually being shifted from pure inorganic fertilizer application to organic fertilization or their combinations in an effort to introduce the concept of integrated soil fertility management (ISFM) in coconut fanning. ISFM may be defined as the combined use of organic or natural and inorganic or chemical fertilizer mi coconut farming aimed at reaching maximum economic Yield through a sustainable, economical, environmental friendly and socially acceptable production system (Magat, 1991).

This project was conducted to (1) explore other alternative fertilizer sources for coconut, (2) to know the effects of pure organic and its combination with inorganic fertilizers on coconut growth and yield and (3) serve as demonstration plots on the effect of fertilizer application and/ or nonapplication on coconut.

This paper covers only the results of four out of fourteen trials conducted in the different parts of the country.

\section{MATERIAL AND METHODS}

\section{Selection of Sites}

Fourteen sites were selected nationwide. The general guidelines and criteria were: (1) suitability of the area for coconut production considering rainfall and soil conditions, (2) strategic location i.e. near or along national roads, (3) nutritionally deficient and less productive and (4) with a system of planting not closer than 8-m spacing.

The MAWA palms - a cross between Malayan dwarf x West African tall planted in 1981 were used as there was no other hybrid types then available.

\section{Selection of Treatment}

The fertilizer treatments were based on the initial leaf nutritional status. Fertilizer sources (organic or inorganic) were determined depending on the deficient elements in a particular site. Since all the sites were deficient $\mathrm{mi} \mathrm{N}$ and $\mathrm{Cl}$, ammonium sulfate and organic fertilizers (as substitute for ammonium sulfate in one of the treatments) were used to supply $\mathrm{N}$ and $\mathrm{KCl}$ or $\mathrm{NaCl}$ (common table salt) to supply $\mathrm{Cl}$. The kind of organic fertilizer used in a particular area depends on its availability mi that area. The fertilizer materials used and their chemical analysis in percent are:

\begin{tabular}{|c|c|c|c|c|c|c|c|c|}
\hline \multirow[t]{2}{*}{ MATERIAL } & \multicolumn{4}{|c|}{ BASED ON LITERATURE } & \multicolumn{4}{|c|}{$\begin{array}{l}\text { BASED ON ANNUAL } \\
\text { ANALYSIS }\end{array}$} \\
\hline & $\mathrm{N}$ & $P$ & K & $\mathrm{Cl}$ & $\mathrm{N}$ & $\mathrm{K}$ & $\mathrm{P}$ & $\mathrm{Cl}$ \\
\hline Ammosul & 20 & 0 & 0 & 0 & 20 & 0 & 0 & 0 \\
\hline $\mathrm{KCl}$ & 0 & 0 & 60 & 44 & 0 & 0 & 60 & 44 \\
\hline $\mathrm{NaCl}$ & 0 & 0 & 0 & 50 & 0 & 0 & 0 & 50 \\
\hline Cow Manure & 2 & 1.5 & 2 & - & 2.04 & 2 & 2.11 & - \\
\hline Corn Cob & 1.84 & 0.91 & 1.19 & $1.70^{*}$ & 2.11 & 1.04 & 1.36 & $8.83 *$ \\
\hline Sagana 100 & 4 & 0 & 0 & - & 4 & 0 & 0 & - \\
\hline
\end{tabular}

* water soluble chloride

- means no available data 


\begin{tabular}{|l|l|l|l|}
\hline \multicolumn{2}{|l|}{ The treatments (kg/tree/year) were follows: } \\
\hline \multicolumn{2}{|l|}{ Polonuling, South Cotabato } & Guisao, Zamboanga City \\
\hline 1) & Control & 1) & Control \\
\hline 2) & $1.0 \mathrm{~kg}(\mathrm{NH} 4) 2 \mathrm{SO} 4+1.8 \mathrm{~kg} \mathrm{NaCl}+1.5 \mathrm{~kg}$ dolomite (Inorg 1) & 2) & $1.5 \mathrm{~kg}(\mathrm{NH} 4) 2 \mathrm{SO} 4+1.5 \mathrm{~kg} \mathrm{KCl}$ \\
\hline 3) & Twice treat 2 (Inorg 2) & 3) & Twice treat 2 \\
\hline 4) & $10 \mathrm{~kg}$ corn cob (Org fert) & 4) & $10 \mathrm{~kg}$ Sagana 100 \\
\hline 5) & $10 \mathrm{~kg}$ corn cob $+1.8 \mathrm{~kg} \mathrm{NaCl}+1.5 \mathrm{~kg}$ dolomite & 5) & $10 \mathrm{~kg}$ Sagana $100+1.5 \mathrm{~kg} \mathrm{KCl}$ \\
\hline Tabaco, Albay & Solana, Cagayan \\
\hline 1) & Control & 1) & Control \\
\hline 2) & $1.5 \mathrm{~kg}(\mathrm{NH} 4) 2 \mathrm{SO}+1.3 \mathrm{~kg} \mathrm{KCl}$ & 2) & $1.5 \mathrm{~kg}$ (NH4) $2 \mathrm{SO} 4+1.4 \mathrm{~kg} \mathrm{KC1}$ \\
\hline 3) & Twice treat 2 & 3) & Twice treat 2 \\
\hline 4) & $10 \mathrm{~kg}$ cow manure & 4) & $10 \mathrm{~kg}$ Sagana 100 \\
\hline 5) & $10 \mathrm{~kg}$ cow manure $+1.3 \mathrm{~kg} \mathrm{KCl}$ & 5) & $10 \mathrm{~kg}$ Sagana $100+1.4 \mathrm{~kg} \mathrm{KC1}$ \\
\hline
\end{tabular}

\section{Experimental Design}

In all sites, the randomized complete block design was used. Each treatment had 12 palms in three to four replicates depending on availability of palms.

\section{Data Gathered}

The vegetative growth data of the palms during prebearing stage were taken yearly. At bearing stage, harvesting was made every two months to obtain the number of nuts, copra weight per nut and copra weight per tree. Copra estimate was based on 20 nut samples per plot taken at random.

\section{Leaf and Soil Analysis}

Aside from the initial leaf and soul analysis, annual leaf sampling was made for chemical analysis of $\mathrm{N}, \mathrm{P}, \mathrm{K}, \mathrm{Ca}, \mathrm{Mg}, \mathrm{Na}, \mathrm{S}, \mathrm{Cl}$ and $\mathrm{B}$, while soil analysis was made before and at the end of the experiment.

\section{RESULTS AND DISCUSSION}

\section{Copra yield per tree}

In the four sites, the Yield of copra per palm per year was greatly improved with the first and second levels of inorganic fertilization (Fig. 1 a to $1 \mathrm{~d}$ ). The two levels did not differ significantly despite doubling the amount of fertilizer in the higher dosage. The application of organic fertilizer alone did not affect favorably the Yield of the palms mi Polonuling, South Cotabato and Tabaco Albay. However in the other two sites of Solana, Cagayan province and Guisao, Zamboanga City, the use of Sagana 100 alone improved the yield over the control by 68 and 161 percent, respectively (Annex table 1) 
It was apparent that the naturally occurring organic fertilizers such as corn cob and cow manure when applied singly did not improve the Yield compared with the manufactured Sagana 100 despite the very favorable rainfall conditions in the sites of the former. It could be that the latter is nutritionally rich and that the former took longer time to decompose to make the nutrients readily available.

Increases $m$ copra yield were generally observed starting the third and fourth year for treatments involving organic fertilizers and on the second and third year for the inorganic fertilized palms.

In all sites, however, when the organic fertilizers were combined with the inorganic $\mathrm{Cl}$ sources such as $\mathrm{KCl}$ or $\mathrm{NaCl}$, much improvements in copra yield were noted although such increases were still below par compared with the inorganic fertilizer treatments.

Hence, unlike in other short-season crops in which organic fertilizer alone immediately affects the present crop being fertilized (Javier, 1992; Barroza, 1988) in coconut, organic fertilizers have to be combined with a chloride source and other elements deficient in the soil to effect increases in yield in three to four years from initial application.

\section{Leaf Nutrients}

The increases $\mathrm{m}$ copra yield were closely associated with increases in the leaf $\mathrm{N}$ and $\mathrm{Cl}$ (in all sites) and $\mathrm{K}$ contents (in some sites) (Table 1). In these treatments where these elements were present in the fertilizers applied, coconut production increased. This was more apparently observed in inorganic-fertilized palms (treatment 2 and 3) which could have been due to the readily available nutrients from these fertilizers promoting immediate or either yield increases. This factor strongly explained the differences in yield of palms.

It is not surprising since $\mathrm{N}$ and $\mathrm{Cl}$ have been popularly implicated to be responsible for yield increases as observed in earlier studies (Magat and Margate, 1990; Magat et al., 1988; Margate et al., 1979; Prudente and Mendoza, 1976). While no correlation had been found between K (from KCl) or $\mathrm{Na}$ (from $\mathrm{NaCl}$ ) with coconut yield, $\mathrm{N}$ was observed to be correlated with the number of nuts while $\mathrm{Cl}$ was correlated with the weight of copra recovery per nut (Magat and Margate, 1990). For the combination of organic fertilizer $+\mathrm{Cl}$ source (treatment 5), the increase in yield was not dramatic as $\mathrm{mi}$ the inorganic treatment. It is possible that $\mathrm{N}$ content from organic fertilizer source was not readily made available. The effect of organic fertilizer maybe indirect. First, it improved soil conditions, then the subsequent improvement in yield.

\section{Effect on Soil Properties}

At the end of the study the consistent effect of the different fertilizer treatments on the soil chemical properties was evident on soil $\mathrm{pH}$ (in all four sites) and a slight improvement in $\mathrm{P}$ and organic matter in some sites (Table 2). Indeed the organic fertilizers acted favorably by maintaining the $\mathrm{pH}$ of the soil while continuous application of inorganic fertilizers tended to make the soul more acidic due to the release of $\mathrm{H}$-ion from ammonium fertilizer.

Though not statistically significant, the organic matter content of plots receiving organic fertilizers were slightly higher than the control and the inorganic fertilizer plots. These were true in Polonuling, South Cotabato; Guisao, Zamboanga City and Solana, Cagayan. Clearly, the addition of organic fertilizer greatly minimum the depletion of organic matter mi the soil. 
The $\mathrm{K}$ contents of the soil were also increased in most areas especially on treatments involving the addition of inorganic $\mathrm{KCl}$ fertilizer. But in Polonuling, South Cotabato, the total $\mathrm{K}$ content was significantly lower in treatments with inorganic fertilizers probably due to the presence of $\mathrm{Ca}, \mathrm{Mg}$ or $\mathrm{Na}$ in the fertilizer materials which could have displaced $\mathrm{K}$.

\section{Economic Implication}

It was shown in the four experiment sites (Table 3) that the lower level of inorganic fertilization was the most profitable treatment. Doubling the dosage did not bring a commensurate increase mi net benefit hence was considered uneconomical because they did not increase yield considerably.

But when $\mathrm{Cl}$ was added to the organic fertilizer, there was a great improvement in yield and hence, the increase Mi profit even if total cost was increased.

On the other hand, organic fertilization mi Guisao, Zamboanga City and Solana, Cagayan which improved the Yield whether applied singly or in combination with $\mathrm{Cl}$, did not come out economical due to Its prohibitive cost which pulled down the net income. Hence, a negative return to investment.

\section{CONCLUSION AND RECOMMENDATIONS}

In coconut the use of inorganic fertilizer could not be totally avoided in favor of organic fertilizers. It is still the most effective treatment if one wants an immediate increase $\mathrm{m}$ coconut yield. However, to lessen total cost and at the same time maintain soil conditions, substitution of organic manures or any available farm wastes for the ammonium sulfate could be the best option for their farmers. The best organic fertilizer sources could be those that are readily available mi the farm/locality which are less expensive (or still better if given free of charge). Because when the organic fertilizer sources are expensive, it is more economical to use pure inorganic fertilizer. Hence, the following are the fertilizer recommendations in $\mathrm{kg}$ per palm per year:

1. Polonuling, South Cotabato (two options depending on availability of fertilizer materials and financial capability of the farmers)
a)
$1.0 \mathrm{~kg}$ ammonium sulfate $+1.8 \mathrm{~kg} \mathrm{NaCl}$ or
b) $10 \mathrm{~kg}$ corn cob $+1.8 \mathrm{~kg} \mathrm{NaCl}$

2. Guisao, Zamboanga City
a)
$1.5 \mathrm{~kg}$ ammonium sulfate $+1.5 \mathrm{~kg} \mathrm{KCl}$

3. Tabaco, Albay (two options) :
a) $\quad 1.5 \mathrm{~kg}$ ammonium sulfate $+1.3 \mathrm{~kg} \mathrm{KCl}$
b) $\quad 10 \mathrm{~kg}$ cow manure $+1.3 \mathrm{~kg} \mathrm{KCl}$

4. Solana, Cagayan
a) $\quad 1.5 \mathrm{~kg}$ ammonium sulfate $+1.4 \mathrm{~kg} \mathrm{KCl}$

Although these findings could be best utilized on MAWA coconut hybrids planted in similar environmental conditions as Mi the study, the fertilizer recommendations can be applied in other coconut populations as experienced in the various coconut collections and other trials in the country. 


\section{ACKNOWLEDGMENT}

The authors wish to express their great appreciation to the staff of the PCA Regional Offices where these studies were conducted headed by the respective Regional Managers for their full support in the conduct of the studies. To the technical staff and laborers of the Agronomy \& Soils Division for their untiring effort $\mathrm{m}^{*}$ the data collection, consolidation, processing and in typing the manuscript the authors are greatly indebted.

Special thanks is due to Department Manager Romero C. Blancaver and to the top PCA Management for their much needed encouragement.

Most of all to HIM for without HIM the authors can do nothing.

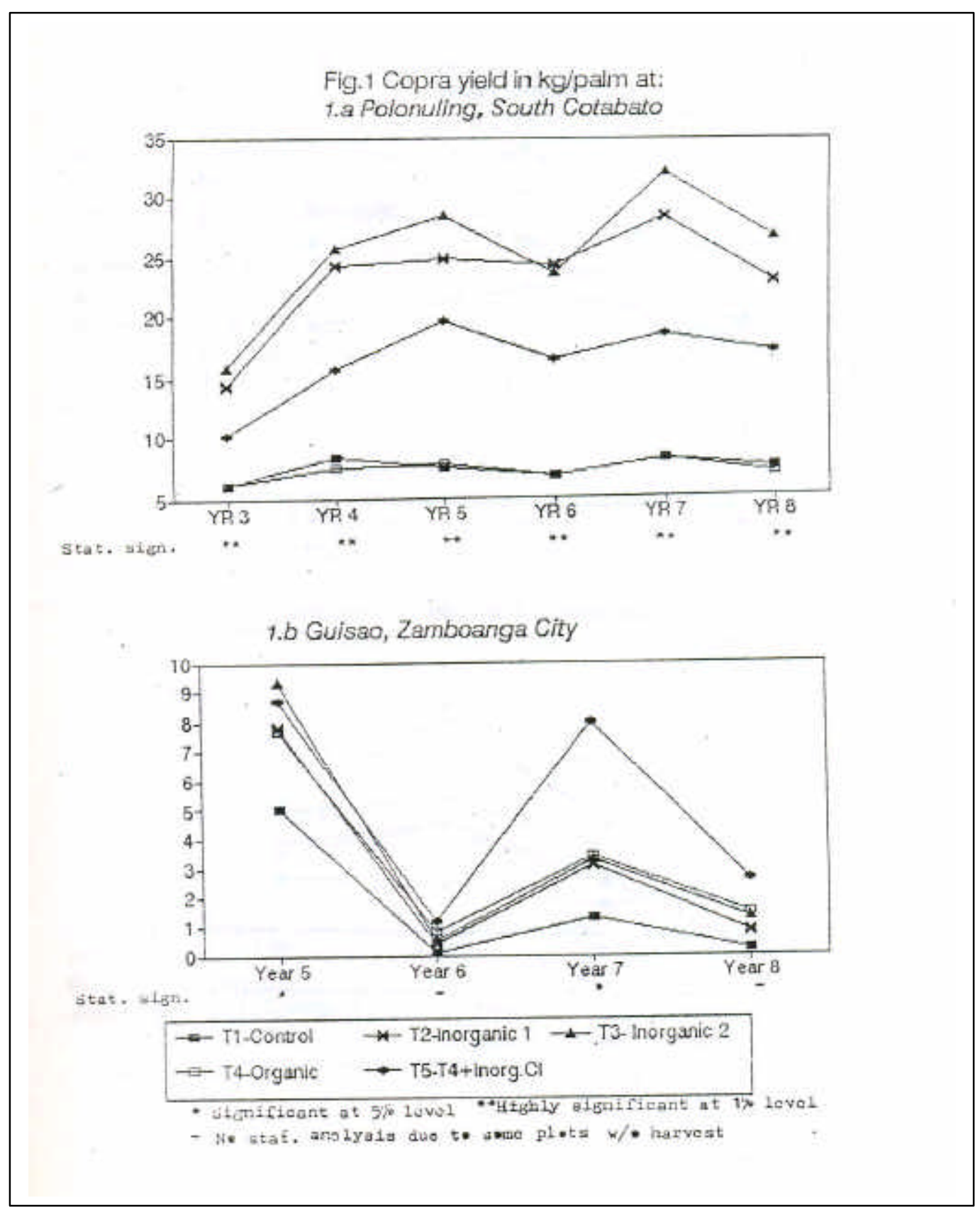




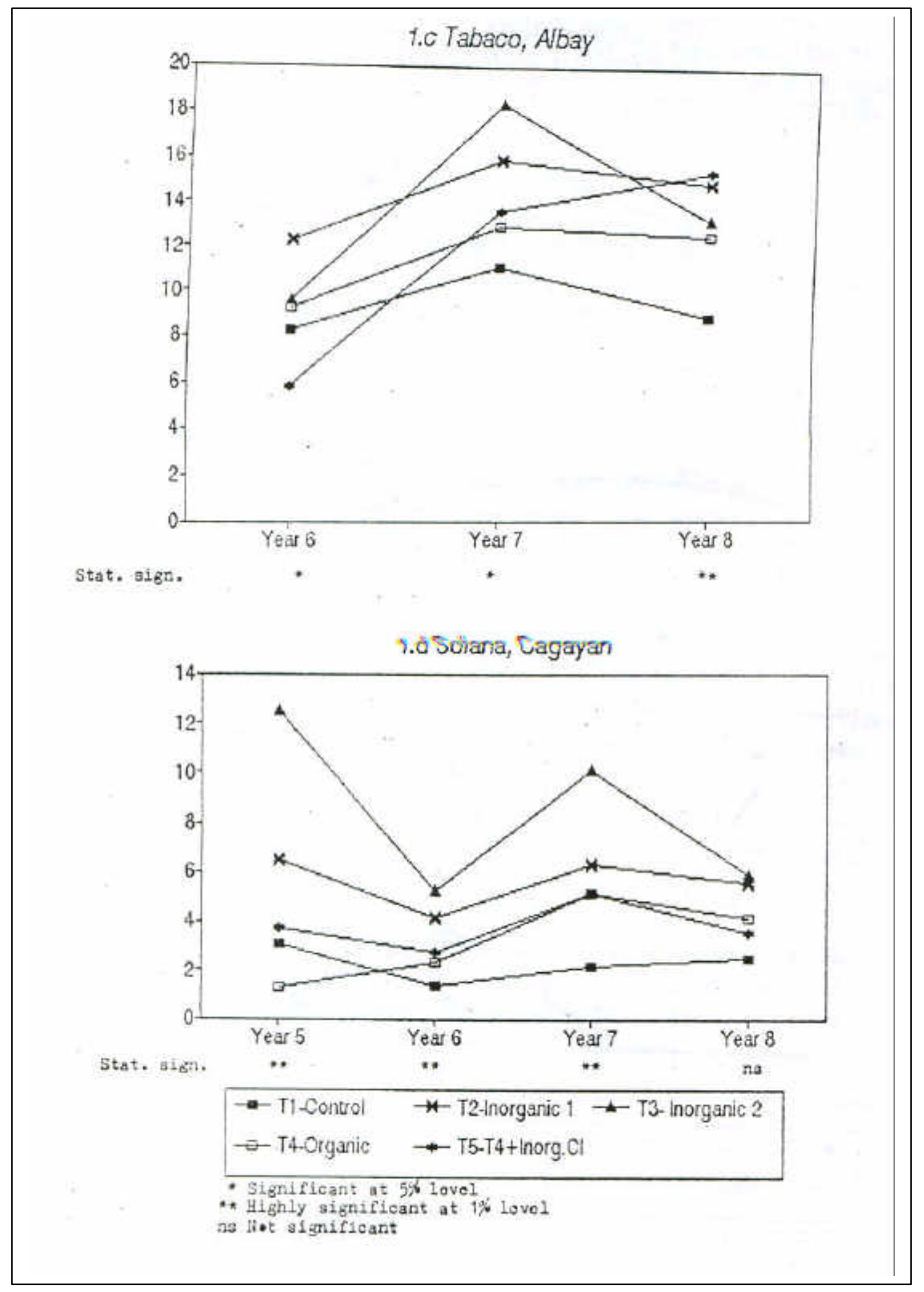




\section{REFERENCES}

BARROGA, J. S. 198 8. Sesbania rostrata: A Green manure for rice-tobacco farm. Greenfields 18(8): 27.

JAVIEF, T. 1992. Orchids grow well on horse manure. PCARRD Farm News,. PFN No. 5879.

MAGAT, S.S., R-Z. MARGATE and P-L. PRUDENTE. 1977. Utilization of common salt (Sodium Chloride) as a fertilization and for the control of leaf spot disease of coconut seedlings. Phil. J. Coconut Studies 2(3) :39-45. -

and J.A. HABANA. 1988. Effects of increasing rates of sodium chloride (common salt) fertilization on coconut palms grown under an inland soil (Tropudalfs), of Mindanao, Philippines. Oleagineux 43(1): 13-17.

1990. The chlorine needs of coconut, CORD 6 (1) 30-51.

1991. Notes on ISFM and Coconut Productivity. Handout. 4 P.

MANGAWANG, C.O. 1993. Farmer's productivity and safety week. Phil. Daily Inquirer Supplement 8 (167) $21-27$

MARGATE, R-Z., S.S.MAGAT, L.M. ALFORJA and J.A. HABANA. 1979. A long-term KCI fertilization study of bearing coconuts in an inland-upland area of Davao. Oleaginueux 34(5): $235-240$

PADRONES, G.D., J.A. HABANA and R.Z. MARGATE. 1985. The profitability of fertilizing coconuts in selected farms mi Mindanao, Philippines. Coconuts Today. 3(1): 116-132.

PRUDENTE, R.L. and A.M.R. MENDOZA, 1976. Response of inland coconuts to inorganic fertilization from field-planting. Phil. J. Coconut Studies 1 (1) : 27-36. 


\begin{tabular}{|c|c|c|c|c|}
\hline SITE & TREATMENT & $\begin{array}{l}\text { NITROGEN } \\
(\mathrm{N})\end{array}$ & $\begin{array}{c}\text { POTASSIUM } \\
(\mathrm{K})\end{array}$ & $\begin{array}{l}\text { CHLORINE } \\
\text { (Cl) }\end{array}$ \\
\hline I. Polonuling & 1. Control & 1.430 & $1.447 a$ & $0.029 d$ \\
\hline \multirow[t]{4}{*}{ South Cotabato } & 2. $1.0 \mathrm{~kg} \mathrm{AS}+1.8 \mathrm{~kg} \mathrm{NaCl}+1.5 \mathrm{Kg} \mathrm{Dol}$ & 1.578 & $1.135 b$ & $0.323 \mathrm{c}$ \\
\hline & 3. Twice treat. 2 & 1.601 & $1.108 \mathrm{~b}$ & $0.475 \mathrm{a}$ \\
\hline & 4. $10 \mathrm{~kg}$ Corn cob & 1.415 & $1.456 \mathrm{a}$ & $0.031 \mathrm{~d}$ \\
\hline & 5. Treat. $4+1.8 \mathrm{~kg} \mathrm{NaCl}+1.5 \mathrm{Dol}$ & 1.560 & $1.171 b$ & $0.389 d$ \\
\hline Stat. Significance & & ns & ** & ** \\
\hline \multirow[t]{5}{*}{ II. Guisao, Zamboanga City } & 1. Control & $1.570 \mathrm{~b}$ & $0.792 \mathrm{c}$ & $0.256 \mathrm{~b}$ \\
\hline & 2. $1.5 \mathrm{~kg} \mathrm{AS}+1.5 \mathrm{~kg} \mathrm{KCl}$ & $1.840 \mathrm{a}$ & $1.264 a$ & $0.624 a$ \\
\hline & 3. Twice. 2 & $1.864 a$ & $1.264 a$ & $0.624 a$ \\
\hline & 4. $10 \mathrm{~kg}$ Sagana 100 & $1.664 a b$ & $0.742 \mathrm{C}$ & $0.251 b$ \\
\hline & 5. Treat. $4+1.5 \mathrm{~kg} \mathrm{KC1}$ & $1.759 a b$ & $1.175 \mathrm{a}$ & $0.531 \mathrm{a}$ \\
\hline Stat. Significance & & ** & ** & ** \\
\hline \multirow[t]{5}{*}{ III. Tabaco, Albay } & 1. Control & 1.731 & $0.705 b c$ & $0.422 \mathrm{~b}$ \\
\hline & 2. $1.5 \mathrm{~kg} \mathrm{AS}+1.3 \mathrm{~kg} \mathrm{KCl}$ & 1.706 & $0.886 \mathrm{~b}$ & $0.459 \mathrm{~b}$ \\
\hline & 3. Twice treat. 2 & 1.713 & $1.164 a$ & $0.450 \mathrm{~b}$ \\
\hline & 4. $10 \mathrm{~kg}$ Cow manure & 1.566 & $0.662 \mathrm{c}$ & $0.352 \mathrm{c}$ \\
\hline & 5. Treat. $4+1.3 \mathrm{~kg} \mathrm{KCl}$ & 1.596 & $1.303 a$ & $0.570 \mathrm{a}$ \\
\hline Stat. Significance & & ns & ** & ** \\
\hline \multirow[t]{6}{*}{ IV. Solana, Cagayan } & 1. Control & 1.433 & 1.635 & $0.284 b$ \\
\hline & 2. $1.5 \mathrm{~kg} \mathrm{AS}+1.4 \mathrm{~kg} \mathrm{KCl}$ & 1.649 & 1.419 & $0.525 a$ \\
\hline & 3. Twice treat. 2 & 1.607 & 1.407 & $0.576 a$ \\
\hline & 4. 10 kg Sagana 100 & 1.573 & 1.120 & $0.348 b$ \\
\hline & 5. Treat. $4+1.4 \mathrm{~kg} \mathrm{Kcl}$ & 1.553 & 1.393 & $0.550 \mathrm{a}$ \\
\hline & & ns & ns & ** \\
\hline \multicolumn{5}{|c|}{$\begin{array}{l}\text { AS - Ammonium sulfate } \\
\text { Dol - Dolomite } \\
\text { Ns - not significant } \\
\text { * - Significant at } 5 \% \text { level } \\
\text { ** - highly significant at } 1 \% \text { level }\end{array}$} \\
\hline
\end{tabular}




\begin{tabular}{|c|c|c|c|c|c|c|c|c|}
\hline \multirow{3}{*}{ TREATMENT } & \multirow{3}{*}{$\mathrm{PH}$} & \multirow{3}{*}{$\frac{P}{(p p m)}$} & \multirow{3}{*}{$\begin{array}{c}\mathrm{K} \\
\text { (H2SO4 } \\
\text { EXT.) } \\
(\mathrm{ppm})\end{array}$} & \multirow{3}{*}{$\begin{array}{c}(0 . \mathrm{M} .) \\
(\%)\end{array}$} & \multirow{2}{*}{\multicolumn{4}{|c|}{ Exch. BASES (m.e./100 g soil) }} \\
\hline & & & & & & & & \\
\hline & & & & & $\mathrm{Ca}$ & $\mathrm{Mg}$ & $\mathrm{Na}$ & $\mathrm{K}$ \\
\hline \multicolumn{9}{|l|}{ Polonuling, South Cotabato } \\
\hline Benchmark & $5.4 a b$ & 3 & - & 7.58 & 3.6 & 5.69 & 0.06 & 0.06 \\
\hline 1. Control & $5.9 b$ & 6.5 & $368 . a$ & 5.5 & $1.48 \mathrm{~b}$ & 0.55 & 0.04 & 0.15 \\
\hline $\begin{array}{l}\text { 2. } 1.0 \mathrm{~kg} \mathrm{AS} 1 /+1.8 \mathrm{~kg} \mathrm{NaCl}+1.5 \\
\mathrm{~kg} \mathrm{Dol} 2 /\end{array}$ & 5.20 & 10 & $137.50 \mathrm{c}$ & 6.07 & $1.50 \mathrm{~b}$ & 0.65 & 0.05 & 0.05 \\
\hline 3. Twice treat. 2 & $5.4 a b$ & 8 & $142.5 \mathrm{c}$ & 6.11 & $2.05 b$ & 0.83 & 0.04 & 0.06 \\
\hline 4. $10.0 \mathrm{~kg}$ corn cob & $6.0 \mathrm{a}$ & 11.8 & $328.8 a b$ & 6.53 & $1.63 \mathrm{~b}$ & 0.63 & 0.04 & 0.18 \\
\hline $\begin{array}{l}\text { 5. } 10.0 \mathrm{~kg} \text { corn cob+ } 1.8 \mathrm{~kg} \mathrm{NaCl}+ \\
1.5 \mathrm{~kg} \mathrm{Dol}\end{array}$ & $6.0 \mathrm{a}$ & 8.5 & $216.3 b c$ & 6.92 & $3.38 \mathrm{a}$ & 1.07 & 0.06 & 0.08 \\
\hline HS 0.05 & $\begin{array}{r}0.70 \\
n s\end{array}$ & ns & $\begin{array}{r}135.90 \\
n s\end{array}$ & ns & $\begin{array}{r}1.31 \\
1.7\end{array}$ & ns & ns & ns \\
\hline C.V (\%) & 5.10 & 28.40 & 25.30 & 19.10 & 29.0 & 36.70 & 28.20 & 58.40 \\
\hline \multicolumn{9}{|l|}{ Guisao, Zamboanga City } \\
\hline Benchmark & 5.7 & 10 & - & 2.28 & - & - & - & 012 \\
\hline 1. Control & $5.9 a$ & 5.33 & $478.33 b$ & 1.66 & 14.76 & 6.15 & 0.04 & $0.25 b$ \\
\hline 2. $1.5 \mathrm{~kg} \mathrm{AS}+1.5 \mathrm{~kg} \mathrm{KCl}$ & $4.6 \mathrm{~b}$ & 4.67 & 1121.67ab & 1.66 & 6.67 & 3.91 & 0.002 & $0.32 \mathrm{ab}$ \\
\hline 3. Twice treat. 2 & $4.4 \mathrm{~b}$ & 3.67 & $2533.33 a$ & 1.66 & 5.4 & 2.37 & 0.02 & $0.32 \mathrm{ab}$ \\
\hline 4. $10 \mathrm{~kg}$ Sagana 100 & $5.7 a b$ & 16 & $308.33 b$ & 2.17 & 1.6 & 5.1 & 0.03 & $0.001 b$ \\
\hline 5. $\mathrm{T} 4+1.5 \mathrm{~kg} \mathrm{KCl}$ & $5.8 a$ & 12 & 1755.00ab & 2.17 & 16.83 & 6.04 & 0.03 & $0.54 a$ \\
\hline HSD 0.05 & 0.80 & ns & 1595.56 & ns & ns & ns & ns & 0.29 \\
\hline 0.01 & ns & & 2160.59 & & & & & 0.39 \\
\hline C.V. (\%) & 5.10 & 45.50 & 24.70 & 38.00 & 38.00 & 67.80 & 44.40 & 33.70 \\
\hline \multicolumn{9}{|l|}{ Tabaco, Albay } \\
\hline 1. Control & $6.2 a$ & 9.7 & 55 & 4.5 & - & - & - & - \\
\hline 2. $1.5 \mathrm{~kg} \mathrm{AS}+1.3 \mathrm{~kg} \mathrm{KCl}$ & $5.90 \mathrm{~b}$ & 8.7 & 85 & 4.2 & - & - & - & - \\
\hline 3. $3.0 \mathrm{~kg} \mathrm{AS}+2.6 \mathrm{~kg} \mathrm{KCl}$ & $5.4 \mathrm{~b}$ & 6.7 & 73 & 3.6 & - & - & - & - \\
\hline 4. $10.0 \mathrm{~kg}$ cow manure & $6.2 \mathrm{ab}$ & 7.3 & 50.7 & 4.6 & - & - & - & - \\
\hline 5. $\mathrm{T} 4+1.3 \mathrm{~kg} \mathrm{KCl}$ & $6.3 \mathrm{a}$ & 9.3 & 72 & 3.9 & - & - & - & - \\
\hline HSD 0.05 & 0.03 & ns & ns & ns & & & & \\
\hline 0.01 & 0.4 & & 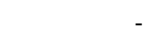 & - & & & & \\
\hline C.V. (\%) & 3.1 & 26.2 & 34.3 & 47.7 & & & & \\
\hline \multicolumn{9}{|l|}{ Solana, Cagayan } \\
\hline 1. Control & $6.2 a$ & 17 & $1333 b$ & 1.3 & $17.2 \mathrm{a}$ & $8.1 \mathrm{a}$ & 0.04 & $0.11 b$ \\
\hline 2. $1.5 \mathrm{~kg} \mathrm{AS}+1.4 \mathrm{~kg} \mathrm{KCl}$ & $4.70 \mathrm{~b}$ & 28 & $4867 a$ & 1 & $11.5 \mathrm{bc}$ & $5.8 \mathrm{~b}$ & 0.03 & $0.76 a$ \\
\hline 3. $3.0 \mathrm{~kg} \mathrm{AS}+2.8 \mathrm{~kg} \mathrm{KCl}$ & 4.4.b & 18 & $4800 a$ & 1 & $11.0 \mathrm{c}$ & $5.8 \mathrm{~b}$ & 0.03 & $0.80 a$ \\
\hline 4. 10.0 kg Sagana 100 & $6.3 a$ & 30 & $896 \mathrm{~b}$ & 1.3 & $16.6 \mathrm{a}$ & 7.4ab & 0.03 & $0.10 \mathrm{~b}$ \\
\hline 5. T4 + $1.4 \mathrm{~kg} \mathrm{KCl}$ & $6.1 \mathrm{a}$ & 42 & 4250abc & 1.2 & 15.9ab & $6.7 \mathrm{ab}$ & 0.04 & $0.63 a$ \\
\hline HSD 0.05 & 0.8 & Ns & 2877 & ns & 4.6 & 2.3 & ns & 0.48 \\
\hline 0.01 & 1.1 & & 3901 & - & 6.3 & & - & 0.65 \\
\hline C.V (\%) & 4.9 & 63.4 & 31.6 & 31.3 & 11.3 & 12.1 & 28.6 & 35.1 \\
\hline
\end{tabular}




\begin{tabular}{|c|c|c|c|c|}
\hline TREATMENT & $\begin{array}{c}\text { GROSS } \\
\text { INCOME (P) }\end{array}$ & $\begin{array}{l}\text { TOTAL COST } \\
(\mathrm{P})\end{array}$ & $\begin{array}{l}\text { NET BENEFIT } \\
(\mathrm{P})\end{array}$ & $\mathrm{BCR}$ \\
\hline \multicolumn{5}{|l|}{ Polonuling, South Cotabato } \\
\hline 1. Control & 7,722 & $2,857.14$ & $4,864.86$ & 1.7 \\
\hline 2. $1.0 \mathrm{~kg} \mathrm{AS}+1.8 \mathrm{~kg} \mathrm{NaCl}+1.5 \mathrm{~kg} \mathrm{Dol}$ & $24,345.75$ & $6,512.22$ & $17,833.53$ & 1.74 \\
\hline 3. Twice treat. 2 & $28,528.5$ & $8,794.5$ & 19,734 & 2.24 \\
\hline 4. $10.0 \mathrm{~kg}$ corn cob & 7,293 & $3,094.52$ & $4,198.48$ & 1.36 \\
\hline 5. $10.0 \mathrm{~kg}$ corn cob $+1.8 \mathrm{~kg} \mathrm{NaCl}+1.5 \mathrm{~kg} \mathrm{Dol}$ & $18,232.5$ & $5,721.43$ & $12,511.07$ & 2.2 \\
\hline \multicolumn{5}{|l|}{ Guisao, Zamboanga City } \\
\hline 1. Control & $1,394.25$ & $2,685.54$ & $-1,291.3$ & -0.48 \\
\hline 2. $1.5 \mathrm{~kg} \mathrm{AS}+1.5 \mathrm{~kg} \mathrm{Kcl}$ & $8,687.25$ & $4,392.96$ & $4,294.3$ & 0.98 \\
\hline 3. Twice treat. 2 & 9,438 & $5,718.57$ & $3,719.4$ & 0.65 \\
\hline 4. $10 \mathrm{~kg}$ Sagana 100 & $3,646.5$ & $7,022.91$ & $-3,556.4$ & -0.49 \\
\hline 5. $\mathrm{T} 4+1.3 \mathrm{~kg} \mathrm{KCl}$ & 8,580 & $8,283.99$ & 296 & 0.04 \\
\hline \multicolumn{5}{|l|}{ Tabaco, Albay } \\
\hline 1. Control & 9,424 & $3,902.4$ & $5,521.6$ & 1.41 \\
\hline 2. $1.5 \mathrm{~kg} \mathrm{AS}+1.3 \mathrm{~kg} \mathrm{KCl}$ & $157,95.2$ & $5,627.2$ & 1,0168 & 1.81 \\
\hline 3. $3.0 \mathrm{~kg} \mathrm{AS}+2.6 \mathrm{~kg} \mathrm{KCl}$ & $14,022.4$ & $6,961.6$ & $7,060.8$ & 1.01 \\
\hline 4. $10.0 \mathrm{~kg}$ cow manure & $13,318.4$ & $5,412.8$ & $7,905.6$ & 1.46 \\
\hline 5. $\mathrm{T} 4+1.4 \mathrm{~kg} \mathrm{KCl}$ & $16,380.8$ & $6,097.6$ & $102,83.2$ & 1.69 \\
\hline \multicolumn{5}{|l|}{ Solana, Cagayan } \\
\hline 1. Control & $2,350.92$ & $2,483.52$ & -132.6 & -0.05 \\
\hline 2. $1.5 \mathrm{~kg} \mathrm{AS}+1.5 \mathrm{~kg} \mathrm{Kcl}$ & $6,235.32$ & $4,580.16$ & $1,655.16$ & 0.36 \\
\hline 3. Twice treat. 2 & $8,330.4$ & $6,271.2$ & $2,059.2$ & 0.33 \\
\hline 4. $10 \mathrm{~kg}$ Sagana 100 & $4,573.92$ & $7,824.96$ & $-3,251.05$ & -0.42 \\
\hline 5. $\mathrm{T} 4+1.4 \mathrm{~kg} \mathrm{KCl}$ & $4,508.4$ & $8,455.2$ & $-3,946.8$ & -0.47 \\
\hline 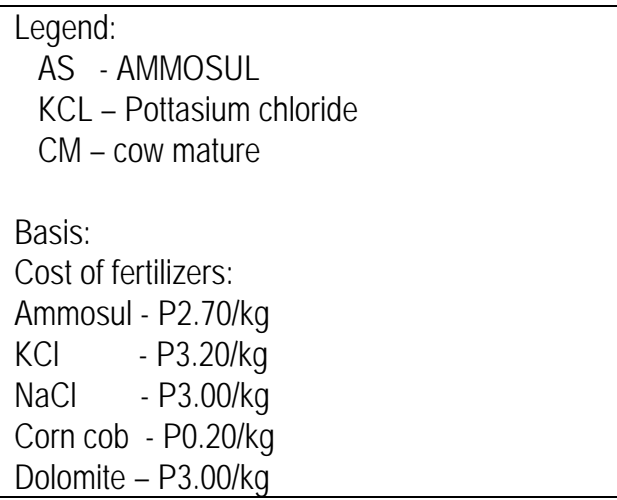 & & $\begin{array}{l}\text { Cow manure }-P 0 \\
\text { Sagana } 100-P \text { - } \\
\text { 2. Labour (mainte } \\
\text { 3. Copra making ( } \\
\text { 4. Copra price - } P \\
\text { 5. Topbrushing ( } \mathrm{T} \\
8 \text { min/tree (6x a yr } \\
\text { 6. Ring-weeding ( } \\
\text { 13 min/tree (6x a) } \\
\text { 7. Fertilizer applic } \\
\text { inorganic fer } \\
\text { organic fert. }\end{array}$ & $\begin{array}{l}0 / \mathrm{kg} \\
00 / \mathrm{kg} \\
\text { ance) }-\mathrm{P} 90.00 / \mathrm{d} z \\
. \mathrm{M} \text {.) }-\mathrm{P} 0.60 / \mathrm{kg} \mathrm{c} \\
.50 / \mathrm{kg} \\
\text { for unfertilized } \mathrm{p} \\
\text { W) for fertilized } \mathrm{pc} \\
\text { ion (F.A.) for } \\
-13 \mathrm{~min} / \mathrm{tree} \\
20 \mathrm{~min} / \text { tree }\end{array}$ & \\
\hline
\end{tabular}




\begin{tabular}{|c|c|c|c|c|c|c|}
\hline TREATMENT & Yr3 & Yr4 & Yr5 & Yr6 & YR7 & Yr8 \\
\hline \multicolumn{7}{|l|}{ Polonuling, South Cotabato } \\
\hline 1. Control & $6.1 \mathrm{c}$ & $8.3 b$ & $7.3 \mathrm{c}$ & $6.7 \mathrm{c}$ & $8.0 \mathrm{c}$ & $7.2 \mathrm{~b}$ \\
\hline 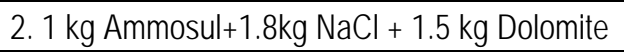 & $14.3 a b$ & $24.2 \mathrm{a}$ & $24.8 \mathrm{a}$ & $24.8 \mathrm{a}$ & $28.3 a$ & $22.7 a$ \\
\hline 3. Twice treat. 2 & $15.8 \mathrm{a}$ & $25.7 \mathrm{a}$ & $28.4 \mathrm{a}$ & $23.5 \mathrm{a}$ & $32.1 \mathrm{a}$ & $26.6 \mathrm{a}$ \\
\hline 4. $10 \mathrm{~kg}$ Corn cob & $6.1 \mathrm{c}$ & $7.3 \mathrm{~b}$ & $7.7 \mathrm{c}$ & $6.7 \mathrm{c}$ & $7.9 \mathrm{c}$ & $6.8 \mathrm{~b}$ \\
\hline $5.10 \mathrm{~kg}$ Corn cob+ $1.8 \mathrm{~kg} \mathrm{NaCl}$ & $10.2 \mathrm{bc}$ & $15.6 a b$ & $19.6 \mathrm{~b}$ & $16.4 \mathrm{~b}$ & $18.4 \mathrm{~b}$ & $17.0 \mathrm{a}$ \\
\hline HSD 0.05 & 4.6 & 10.3 & 8.5 & 4.3 & 7.3 & 6.2 \\
\hline 0.01 & 5.9 & 13.3 & 11.1 & 5.6 & 9.4 & 7.9 \\
\hline C.V. (\%) & 19.4 & 28.1 & 21.6 & 12.4 & 17.1 & 17.0 \\
\hline \multicolumn{7}{|l|}{ Guisao, Zamboanga City } \\
\hline 1. Control & - & - & $5.0 \mathrm{~b}$ & $0.1^{*}$ & $1.3 a b$ & $0.2^{*}$ \\
\hline 2. $1.5 \mathrm{~kg} \mathrm{Ammosul+} 1.5 \mathrm{~kg} \mathrm{KCl}$ & - & - & $7.8 \mathrm{ab}$ & 0.4 & $8.1 \mathrm{ab}$ & 0.8 \\
\hline 3. Twice treat. 2 & - & - & $9.3 a$ & 0.5 & $8.8 \mathrm{a}$ & 1.8 \\
\hline 4. $10 \mathrm{~kg}$ Sagana 100 & - & - & 7.7ab & 0.8 & $3.4 a b$ & 1.5 \\
\hline 5. $100 \mathrm{~kg}$ Sagana $100+1 \mathrm{~kg} \mathrm{KCl}$ & - & - & $8.7 a b$ & 1.2 & $8.0 a b$ & 2.6 \\
\hline $\begin{array}{c}0.05 \\
\text { HSD } \\
0.01 \\
\text { CV }(\%)\end{array}$ & & & $\begin{array}{r}2.9 \\
\mathrm{nS} \\
18.3\end{array}$ & & $\begin{array}{r}7.3 \\
\mathrm{~ns} \\
43.6\end{array}$ & \\
\hline \multicolumn{7}{|l|}{ Tabaco, Albay } \\
\hline 1. Control & - & - & - & $8.3 b$ & $11.1 \mathrm{~b}$ & $8.8 \mathrm{~b}$ \\
\hline 2. $1.5 \mathrm{~kg} \mathrm{Ammosul} \mathrm{+} \mathrm{1.kg} \mathrm{KCl}$ & - & - & - & $12 . \mathrm{a}$ & 15.9ab & $14.8 \mathrm{a}$ \\
\hline 3. Twice treat. 2 & - & - & - & $9.6 \mathrm{~b}$ & $18.3 \mathrm{a}$ & $13.2 \mathrm{a}$ \\
\hline 4. $10 \mathrm{~kg}$ Cow manure & - & - & - & $9.2 b$ & $12.9 a b$ & $12.5 a b$ \\
\hline 5. Treat $4+1.3 \mathrm{~kg} \mathrm{KCl}$ & - & - & & $5.5 \mathrm{c}$ & 13.6ab & $15.4 \mathrm{a}$ \\
\hline $\begin{array}{l}\text { HSD } 0.05 \\
0.01 \\
\text { C.V. }(\%)\end{array}$ & & & & $\begin{array}{r}2.5 \\
\text { ns } \\
20.7\end{array}$ & $\begin{array}{r}6.2 \\
\text { ns } \\
8.9\end{array}$ & $\begin{array}{r}4.3 \\
5.8 \\
38.2\end{array}$ \\
\hline \multicolumn{7}{|l|}{ Solana, Cagayan } \\
\hline 1. Control & - & - & $3.1 \mathrm{~b}$ & $1.4 \mathrm{c}$ & $2.2 \mathrm{~b}$ & 2.5 \\
\hline 2. $1.5 \mathrm{~kg} \mathrm{Ammosul+} 1.4 \mathrm{~kg} \mathrm{KCl}$ & - & - & $6.5 a b$ & $4.2 a b$ & $6.3 \mathrm{ab}$ & 5.6 \\
\hline 3. Twice treat. 2 & - & - & $12.3 \mathrm{a}$ & $5.3 a$ & $10.1 \mathrm{a}$ & 5.19 \\
\hline 4. $10 \mathrm{~kg}$ Sagana 100 & - & - & $1.3 \mathrm{~b}$ & $2.4 b c$ & $5.2 b$ & 4.2 \\
\hline $\begin{array}{l}\text { 5. } 10 \mathrm{~kg} \text { Sagana } 100+ \\
1.4 \mathrm{KCl}\end{array}$ & - & - & 3.6 & $2.6 \mathrm{bc}$ & $5.2 b$ & 3.6 \\
\hline HSD 0.05 & & & 6.8 & 2.4 & 4.2 & ns \\
\hline 0.01 & & & 9.8 & 3.5 & 6.2 & ns \\
\hline C.V. (\%) & & & 66.1 & 40.3 & 38.8 & 29.0 \\
\hline
\end{tabular}

